\section{South African doctors demand action on "unethical" colleagues}

Pat Sidley Johannesburg

Several South African doctors are considering taking action to force the Health Professions Council to initiate an investigation into the conduct of the doctor who headed up the apartheid government's chemical and biological warfare programme.

They are also asking the council, which is the statutory body governing the medical, dental, and other health professions, to take action against a list of doctors implicated in unethical conduct in testimony before the Truth and Reconciliation Commission.

Dr Wouter Basson is a cardiologist who is being tried for crimes associated with his role at the head of the programme. These crimes include murder, fraud, drug manufacturing, and drug dealing.

Dr Basson refused to give full testimony to the Truth and Reconciliation Commission and did not apply for amnesty; these actions opened the way for the criminal prosecution. He has retained his job in the public health sector as a cardiologist, at least until the outcome of the trial is known.

The Health Professions Council has not begun an inquiry into his conduct, claiming instead that it would wait for the criminal trial to end because it would be difficult to get witnesses until that time.

The South African Medical Association, the voluntary professional association for doctors, has allowed Dr Basson to remain a member but has initiated an investigation into his membership. It was only recently brought to public attention that Dr Basson was still registered to practise.

Among those who have now complained to the council is Professor Joe Veriava, who was instrumental, with a handful of other doctors, in taking the council to court to compel it to

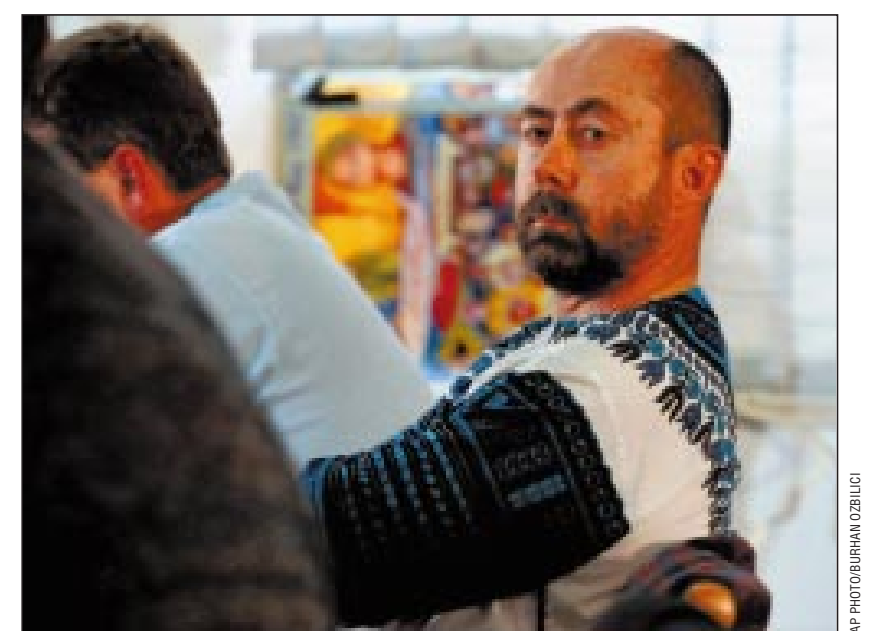

Dr Wouter Basson, former head of the South African army's chemical weapons project, still practises as a doctor

inquire into the death of the political activist Steven Biko.

Up until that time the council had refused to take action against the doctors who attended to Mr Biko after he was fatally assaulted while in police custody. Two doctors have complained to the council and have subsequently received anonymous death threats.

Now a group of doctors from the Health and Human Rights Project affiliated with the Univer- sity of Cape Town is trying to encourage the council to pay more attention to Dr Basson's case. According to Leslie London, associate professor in the university's community health department, many doctors have reacted with anger to the apparent inertia of the council. They had, he said, previously asked the council to look into the conduct of the doctors named at the Truth and Reconciliation Commission but had received no reply.

\section{Canadian provinces want to cut tests to meet doctor shortage}

David Spurgeon Quebec

A serious shortage of doctors is causing some Canadian provinces to try to persuade their medical licensing authorities to waive traditional competency tests. Their action was criticised by the new president of the Canadian Medical Association, Dr Hugh Scully, as "a shortsighted way" of looking at the problem.

Delegates at the association's annual meeting agreed and adopted a resolution calling for "international medical graduates" to undergo the same competency evaluation standards as those used for Canadian graduates.

Other resolutions called for increased training capacities for both undergraduate and graduate medical education and adoption of the principle of "national self sufficiency in the production and retention of physicians." Delegates called for the provincial governments to supply funds for increasing the number of doctors.

Dr Scully did not identify the provinces that are said to be urging dilution of standards, but he referred to two provinces, unnamed, in the west of the country. He said that provincial medical associations had intervened to prevent this happening.

He said that the shortage of doctors could be accurately described as a crisis: there is currently a shortfall nationally of 180 anaesthetists, which has caused operations across the country to be cancelled.

Other shortages exist in cardiac care; paediatrics; obstetrics; and ear, nose, and throat specialties. Shortages exist in both urban and rural centres.

\section{Romanian GPs to take control of their practices}

Tudor Toma Bucharest

The Romanian government will be giving some GPs responsibility for the practices where they currently work, $\mathrm{Mr}$ Hajdu Gabor, the state secretary of health, has announced. GPs who have worked in their practices for a certain number of years will be offered the new arrangement.

Starting in September 1999 the GPs will have to sign a renting contract with a zero rent for one year. This period of free rent may be extended to five years. The government hopes that after five years most of the doctors will be able to afford to buy their practices.

Most of the surgeries are in poor condition and are currently owned by either local councils or regional health authorities. Up to now, GPs have had no control of the practice facilities, and development has depended on the regional health budget and the regional manager's will to improve the standards in individual surgeries.

Doctors will now receive an administration fund from the National Health Insurance House (Casa Nationala de Asigurari) to run their practices. They will have full responsibility for deciding where the money should go.

The sum will be in the range of 12 million leu (£467; \$747) per month per practice, out of which practitioners will have to pay for office supplies and equipment, utilities, and assistants' salaries. They will then pay themselves from what is left. The Romanian government hopes that under these reforms GPs will become the true managers of their practices.

Most doctors think that it is a good idea in theory but are worried that, as they have had no formal training in management, they will not be able to cope. Some, however, have been swift to sign the renting contracts. $\square$ 